Research Article

\title{
Statistical Characteristics of Polymer Grouting Material Microstructure
}

\author{
Juan Wang $\mathbb{D},{ }^{1,2}$ Xun Li $\mathbb{D},{ }^{2}$ Hongyuan Fang $\mathbb{D}^{2},{ }^{2}$ Juan Zhang, ${ }^{1}$ and Jinping $\mathrm{Li}^{1}$ \\ ${ }^{1}$ CCCC First Highway Consultants Co., Ltd., \\ State Key Laboratory of Road Engineering Safety and Health in Cold and High-Altitude Regions, Xi'an, Shaanxi 710075, China \\ ${ }^{2}$ School of Water Conservancy Engineering, Zhengzhou University, Zhengzhou 450001, China \\ Correspondence should be addressed to Xun Li; lixun_zzu@163.com and Hongyuan Fang; fanghongyuan@zzu.edu.cn
}

Received 5 June 2020; Revised 15 July 2020; Accepted 5 August 2020; Published 30 August 2020

Academic Editor: Grzegorz Golewski

Copyright (C) 2020 Juan Wang et al. This is an open access article distributed under the Creative Commons Attribution License, which permits unrestricted use, distribution, and reproduction in any medium, provided the original work is properly cited.

\begin{abstract}
The two-component foaming polyurethane is a kind of grouting material that has recently been widely used in engineering structural repair. Its physical and mechanical properties are closely related to its microstructure. Therefore, the qualitative and quantitative analysis of polymer microstructure has always been a research hotspot. The statistical characteristics of polymer grouting material microstructure are investigated by six groups of specimens with different densities, and the density varies from 0.1 to $0.6 \mathrm{~g} / \mathrm{cm}^{3}$. The microstructure morphology of polymer was observed and described by scanning electron microscopy (SEM), and the microstructure feature parameters were extracted and calculated by image processing technology. The quantitative analysis of section cell roundness distribution, cell diameter distribution, and polymer porosity shows that low-density polymer materials have anisotropy. While the density exceeds $0.3 \mathrm{~g} / \mathrm{cm}^{3}$, the cell structure tends to be spherical. The section cell diameters obey a normal distribution, and when the density increases, the cell diameter decreases. The porosity of the polymer has a linear negative correlation with the density. The polymer matrix has a density of $1.21 \mathrm{~g} / \mathrm{cm}^{3}$. The microstructural information obtained in this study will help establish a cell-based model to explain the mechanical response of rigid polymer foams.
\end{abstract}

\section{Introduction}

Nonwater reacted polymer grouting materials produced via a two-component polyurethane foam are a new kind of grouting materials [1]. Under grouting pressure, the polymer material reacts chemically, expands in volume, and rapidly solidifies [2]. This material has a good compressive strength [3], relatively high tensile strength [4], and good water impermeability [5]. It has been widely used in foundation reinforcement, void filling, antiseepage plugging, and other repair projects [6-9].

With the increase in engineering applications, the engineering properties of polymer grouting materials have also received extensive attention. In recent years, the research on the engineering properties of rigid polyurethane (RPU) has mainly focused on the relationship between material density, cellular microstructure, and physicomechanical properties. Hawkins et al. [10] studied the relationship between cell morphology, density, and mechanical properties in different positions of polyurethane samples with three mold sizes. The results showed that there is a relationship between cellular morphology and compression modulus and collapse stress in foamed plastics. And the shape and direction of cell not only affect the failure mechanism, but also affect the mechanical data. The authors of [11-14] studied the stressstrain behavior, microstructure characteristics, fatigue behaviour, and failure mode of RPU grouting materials under uniaxial compression, dynamic compression, and cyclic loading. Studies have shown that RPU grout materials with different densities show elastoplastic or atypical brittle characteristic; the main mechanical properties increase with increasing of density. In addition, the compressive failure of the material was caused by a yielding of the cell edges, and the manifestation of the microscopic fatigue failure was the expansion of the cracks in the cell walls and buckling of the cell edges. Ridha et al. [15] conducted experiments on the 
tensile properties of RPU materials, studied their microstructure characteristics, such as the size and geometric composition of the cells and struts, and defined the cell edges. The results showed that the cells were elongated under a tensile load; therefore, the material exhibited anisotropy, and the flexure of the struts at the cell edges were the main mechanism controlling the deformation and failure. Zheng et al. [16] conducted a study on RPU grouting materials through three-point bending load and uniaxial compression tests and analyzed the mechanical behavior using a cell structure model. The results showed that the bending and compressive strengths of the polymer increased with the increase in density. In addition, with the increase in the density, the cell size decreased, and the degree of edge and corner polymerization between the cells decreased. Therefore, the antidamage ability of the cell was enhanced and the compression strength finally increased. Wu and $\mathrm{He}$ et al. $[17,18]$ studied the failure of RPU foam under a high temperature and vibration, and the degree of damage after treatment was evaluated through its tensile properties. The results showed that the tensile strength decreases with the increase in vibration amplitude and time, and the vibration failure of RPU foam was mainly due to the existence of microcracks in the cell structure. With the increasing heattreating temperature, the stress concentration in the RPU foam increased, and the tensile strength and modulus decreased due to the comprehensive effect of cell wall degradation and the generation of new defects.

The microimages of polyurethane polymers directly reflect many characteristics of the cellular structure. Through image analysis, many characteristics of the cell structure can be measured and characterized. According to the different image types, the image analysis and characterization methods of cell structure can be divided into 2D image analysis method and 3D image analysis method $[19,20]$. The comparison between the two methods is shown in Table 1.

Two-dimensional image analysis methods include microimage acquisition and computer image analysis methods. The 2D image of the cell structure is usually obtained by optical microscope (OM) [21-23] or scanning electron microscope (SEM) [24, 25]. The objective magnification of SEM can be changed from 10 times to more than 300,000 times. It can be used to detect small structural characteristics of foam, such as structural defects that damage the foam of samples $[17,18]$. Computer image analysis method consists of image processing technology and image analysis technology [26]. Image processing technology corrects the blurring and other defects in the cell structure image and strengthens the cell information, so as to achieve the basic goal of correction and improvement of image quality. Image graying and threshold segmentation are common methods in $2 \mathrm{D}$ image processing. Computer image analysis technology refers to the extraction, description, and recognition of the characteristics (porosity, cross-section size, and crosssection shape of the cell) in the cell structure image based on a certain algorithm. However, the 2D image of cellular structure is a cross-section image of 3D structure, so the cell structure characteristics reflected in 2D images are not directly equivalent to the actual size of the feature in threedimensional space. Therefore, it is necessary to transform the features of $2 \mathrm{D}$ cell structure image into the actual $3 \mathrm{D}$ cell structure parameters according to the principles of solid geometry and statistics [27, 28].

In the same way, the $3 \mathrm{D}$ image analysis method needs to acquire the micro $3 \mathrm{D}$ structure image and carry out the computer $3 \mathrm{D}$ image processing. The $3 \mathrm{D}$ cell structure image needs to be obtained by $3 \mathrm{D}$ imaging methods, including optical tomography(OT) [29], laser confocal microscopy (LCM) [30], magnetic resonance imaging (MRI) [31, 32], $\mathrm{X}$-ray computerized tomography (X-CT) [30,33], and so on. On the basis of complex 3D image processing algorithm, three-dimensional cell structure analysis and characterization of foam materials can be made by using a professional $3 \mathrm{D}$ image processing toolkit. Watershed segmentation and minimum intensity pixelization-based method are two commonly used algorithms for computer 3D image processing $[34,35] .3 \mathrm{D}$ images can reflect the cell morphology of foam plastics in three dimensions, and the cell structure information is much richer than $2 \mathrm{D}$ images. However, at present, this technology needs to be improved. The acquisition of $3 \mathrm{D}$ image is too expensive, and the processing is complex and time-consuming, so it has not reached the stage of extensive practical application.

In this study, the microstructure of polymer grouting materials was observed and described by SEM, and the geometric characteristics of the size and shape of the cells under different densities were statistically analyzed with image processing technology. The quantitative relationship between geometric parameters such as cell content and size to polymer density are established. The purpose of this work is to provide a strategy for the research on the structure and performance of polymer grouting materials and suggest a potential method to study the mechanical properties and strength mechanism of polymer.

\section{Statistics of Polymer Microstructure Characteristics}

2.1. Test Overview. The two-component foaming polyurethane is primarily composed of polyols and isocyanates. The raw materials (Wanhua Energysav Science \& Technology Group Co., Ltd., Yantai, Shandong, China) for the test are shown in Figure 1. Specimen casting, density measurement, and microstructure observation were carried out on the basis of the current standard GB/T 8813-2008 [36], GB/T 63432009 [37], and GB/T 12811-1991 [38]. The test mold adopts a split central cylinder with an inner diameter of $50 \mathrm{~mm}$ and a height of $600 \mathrm{~mm}$, and the wall thickness is $10 \mathrm{~mm}$. The onestep mechanical pouring foaming process was used. The two components, called white and black materials, were mixed evenly and quickly into the mold at room temperature (ambient temperature $15^{\circ} \mathrm{C}-20^{\circ} \mathrm{C}$ ). After mixing, the two materials reacted violently and foamed rapidly, and the mold space was quickly filled. After $30 \mathrm{~min}$, the specimen was removed from the mold after forming, and after standing for $3 \mathrm{~h}$, the specimen was cut into a cylinder with a height of $100 \mathrm{~mm}$. The weight of each specimen was taken and 
TABLE 1: Comparison of 2D and 3D image analysis methods.

\begin{tabular}{|c|c|c|c|}
\hline $\begin{array}{l}\text { Image analysis } \\
\text { method }\end{array}$ & $\begin{array}{l}\text { Image acquisition } \\
\text { method }\end{array}$ & $\begin{array}{l}\text { Computer image analysis method (software } \\
\text { packages and algorithms) }\end{array}$ & Characteristic \\
\hline $2 \mathrm{D}$ & $\begin{array}{c}\text { OM } \\
\text { SEM }\end{array}$ & $\begin{array}{l}\text { Adobe Photoshop } \\
\text { Matlab } \\
\text { ImageJ } \\
\text { Image-Pro plus } \\
\text { Image graying } \\
\text { Threshold segmentation }\end{array}$ & $\begin{array}{c}\text { Flexibility } \\
\text { Simple operation } \\
\text { Wide amplification range } \\
\text { High resolution } \\
\text { Simple and fast target information } \\
\text { processing and extraction } \\
\text { 2D to 3D conversion required }\end{array}$ \\
\hline $3 \mathrm{D}$ & $\begin{array}{c}\text { X-CT } \\
\text { MRI } \\
\text { OT } \\
\text { LCM }\end{array}$ & $\begin{array}{c}\text { Mavi } \\
\text { Avizo } \\
\text { Aphelion 3D } \\
\text { Watershed segmentation } \\
\text { Minimum intensity pixelization-based method }\end{array}$ & $\begin{array}{c}\text { Rich information of 3D structure } \\
\text { More information can be extracted } \\
\text { No damage to the interior of the target test } \\
\text { piece } \\
\text { High cost of image acquisition } \\
\text { Complex processing }\end{array}$ \\
\hline
\end{tabular}

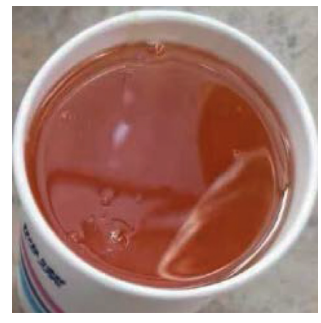

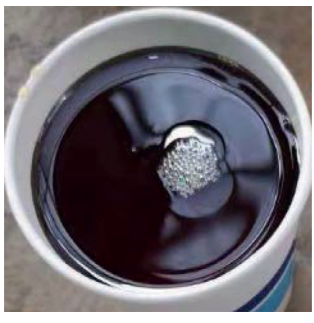

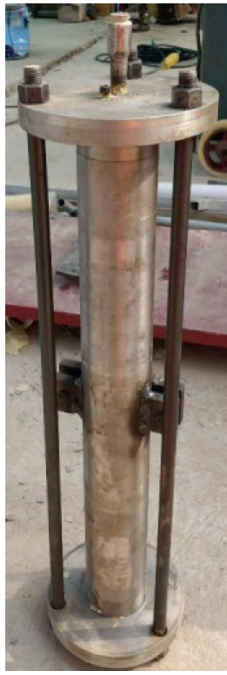

(c)

(b)

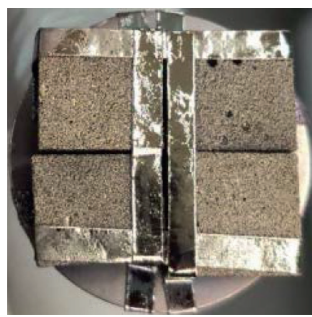

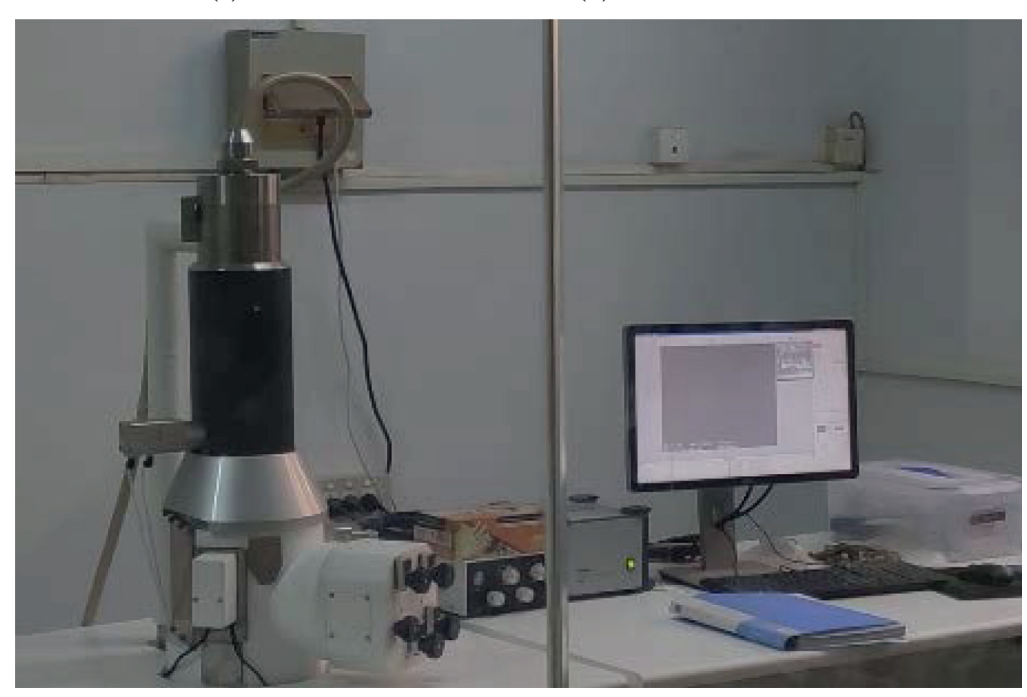

(g)

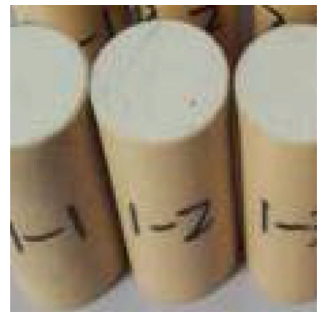

(d)

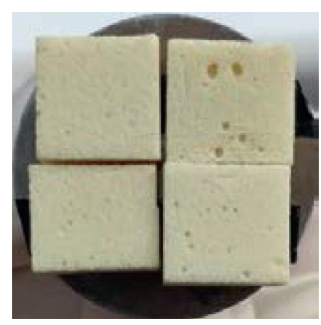

FIGURE 1: Raw material, sample preparation, and the primary instrument. (a) Material A; (b) material B; (c) grouting forming polymer; (d) specimen of polymer; (e) observation sample; (f) target section spraying gold; (g) SEM. 
recorded, its actual density was calculated, and the specimens whose density met the requirements were numbered. To analyze the microstructure morphology and statistical characteristics of the polymer grouting materials, six groups of densities were designed, which were $0.1,0.2,0.3,0.4,0.5$, and $0.6 \mathrm{~g} / \mathrm{cm}^{3}$. The measured densities were $0.11,0.25,0.31$, $0.40,0.51$, and $0.56 \mathrm{~g} / \mathrm{cm}^{3}$, respectively.

The microstructure of the polymer samples was observed by SEM. The samples used for the SEM test were processed as follows. A cylindrical core sample was taken along the center of the specimen with a core drilling machine (round drill bit, outer diameter $38 \mathrm{~mm}$, inner diameter $2.8 \mathrm{~mm}$ ) and then cut to a thickness of $20 \mathrm{~mm}$ on a machine tool. To improve its conductivity, the target section of the sample was sprayed with gold prior to the observation. A scanning electron microscope (KYKY-EM6200, Beijing Zhongke Science and Technology Co., Ltd., Beijing, China) was used to observe the section of the sample, and structure images of the cells were taken.

\subsection{Microstructure Feature Extraction}

2.2.1. Microstructure Variables. The polymer grouting material has a kind of cell structure, whose internal feature parameters mainly include cell shape [34], cell size [39], cell size distribution [25], and cell content [10]. The parameters of roundness, cell diameter, and porosity are often used to measure the above geometric characteristics. The definition and calculation formula of each variable are as follows.

(1) Section roundness $(n)$ is the percentage of the ratio of $4 \pi$ times the area to the perimeter square [27], represented in (1). The section roundness indicates the degree to which each cell section tends to be round. The percentage is closer to $100 \%$, and the shape of the cell section is closer to be a circle; that is, when $n=100 \%$, the cell section is circular.

$$
n=\frac{4 \pi \cdot s}{c^{2}} \times 100 \%
$$

where $c$ is the perimeter of the cell section, and $s$ is the area of the cell section.

(2) Section cell diameter $(d)$ is the calculated size of a single cell in the cross-section. Each cell is equivalent to a circle, and the cell size is represented by the equivalent diameter of the circle. The length of the line segment passing through the centroid of the cell was measured every $2^{\circ}$, and then the average value, which is recorded as the cell diameter, is calculated.

Section average cell diameter $(\bar{d})$ is the arithmetic mean of all cell diameters in the statistical section, represented as

$$
\bar{d}=\frac{\sum n_{i} d_{i}}{\sum n_{i}}
$$

In this formula, $d_{i}$ is a possible value of the cell section diameter, and $n_{i}$ is the number of cells with a cell diameter of $d_{i}$.
Standard deviation of section cell diameter $(S)$ is the distribution of the diameter of the cells in the statistical section, represented as

$$
S=\sqrt{\frac{1}{N-1} \sum_{i=1}^{N}\left(d_{i}-\bar{d}\right)^{2}}
$$

where $N$ is the total number of cells in the sample, $d_{i}$ is the diameter of any cell section, and $\bar{d}$ is the section average cell diameter.

It is assumed that the cell is spherical and disordered. When the number of cells on the SEM image tends to infinity, there is also a quantitative relationship between the section average cell area and the average cell diameter. As shown in Figure 2, when a 2D image plane passes through a cell, the distance from the crosssection to the center of the cell is random, and the section area of the cell changes accordingly.

When the number of cells passing through the twodimensional image plane is large, the average crosssectional area of cells $(\bar{A})$ tends to a fixed value related to the cell diameter $(D)$ [11], which is shown as follows:

$$
\bar{A}=\int_{0}^{R} A \frac{d x}{R}=\frac{1}{R} \int_{0}^{R} \pi\left(R^{2}-x^{2}\right) d x=\frac{2}{3} \pi R^{2}=\frac{\pi}{6} D^{2}
$$

The cell diameter $(D)$ can also be expressed by the average cell cross-sectional area $(\bar{A})$ :

$$
D=\left(\frac{6}{\pi}\right)^{1 / 2} \bar{A}^{1 / 2}=1.382 \bar{A}^{1 / 2},
$$

where $A$ is the area of any cell section, $x$ is the distance from the section to the cell center, and $R$ is the cell diameter.

The formula for calculating the standard deviation of cell diameter can be obtained by the differential equation (5):

$$
S_{D}=\left(\frac{6}{\pi}\right)^{1 / 2}(\bar{A})^{-1 / 2} S_{A}=1.382(\bar{A})^{-1 / 2} S_{A},
$$

where $S_{D}$ is the standard deviation of cell diameter and $S_{A}$ is the standard deviation of the sectional area of the cell.

(3) Porosity $(f)$ is the ratio of the gas phase volume to the total volume, represented as

$$
f=\frac{V_{s}}{V_{f}} \text {. }
$$

In this formula, $V_{s}$ is the volume of the gas phase, and $V_{f}$ is the total volume of the polymer. 


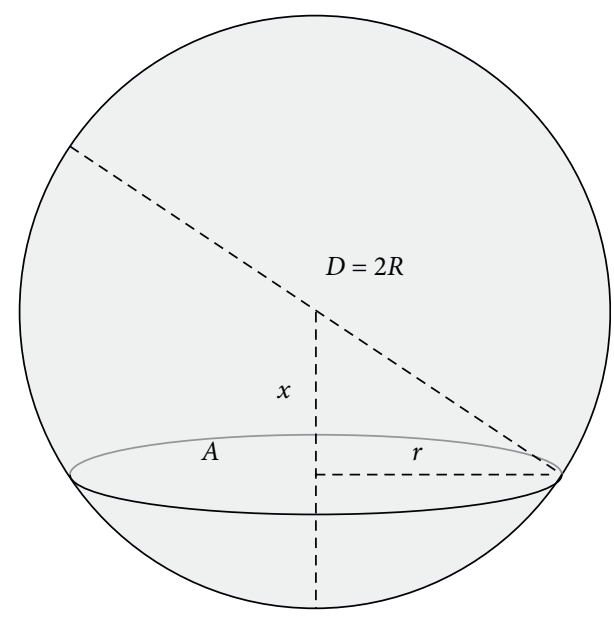

FIgURE 2: Method of converting 2D area measured from SEM image to $3 \mathrm{D}$ diameter of a foam cell in a RPU specimen.

It is difficult to directly measure the volume of the gas phase; therefore, the gas phase is determined according to the basic equation (8) of quantitative metallography [40].

$$
V_{V}=A_{A}=L_{L}
$$

In this formula, $V_{V}$ is the volume fraction of the measured phase, $A_{A}$ is the area fraction of the measured phase, and $L_{L}$ is the line segment fraction of the measured phase.

2.2.2. Analysis of the Structural Variables of Polymer Grouting Materials. Image processing technology was used to preprocess the SEM image. According to the definition of the microstructure variables, relevant geometric parameters in the image are extracted and the distribution characteristics are analyzed. The main steps are as follows.

(1) Image preprocessing: The noncell information pixels on the picture are cut out, and the image with the largest size range is used. The size of the cropped image is approximately $4 \mathrm{~mm} \times 4 \mathrm{~mm}$, and each image can contain hundreds of cells, as shown in Figures 3(a) and 3(b).

(2) Image reconstruction: Under the principle of image fidelity, the cells in the SEM image are filled with black by ImageJ software. Then, the filled SEM image is binarized to obtain black cells in a white background through MATLAB software, so that the target cells are highlighted (none of the above operations change the image pixel density). The reconstructed SEM image is shown in Figure 3(c).

(3) Boundary processing: First, the incomplete cells at the edges of the picture are removed. Some of the cells in the material's microstructure will be in contact with each other, and the smaller the density is, the more obvious this phenomenon is; therefore, the boundaries need to be processed. Based on the original image, the cells that touch each other are segmented by the Split Objects function of the Image-Pro Plus software. The SEM image of the edge cell removal and the contact cell segmentation is shown in Figure 3(d).

(4) Microstructure variable statistics: A pixel analysis is performed on the image obtained from steps 2 and 3 by the Image-Pro Plus software. The porosity is obtained from the reconstructed image, and the other structural variable values are calculated from the removed and segmented image. All measured samples are counted, the microstructure variables of the polymers are calculated, and their distribution characteristics are analyzed.

\section{Results and Discussion}

3.1. Microstructure of Polymers. The formation of cells in polyurethane polymer materials is mainly described by the foaming process. Generally, the foaming process is divided into three stages: the nucleation of small bubbles in the liquid polymer, growth of small bubbles to a predetermined volume, and stabilization of the cell structure [24]. After curing, the polyurethane polymer material can be prepared. Figure 4 shows the microstructure of polymers with different magnification at different densities. Figures 4(a), 4(d), 4(g), $4(\mathrm{j}), 4(\mathrm{~m})$, and $4(\mathrm{p})$ are SEM images of the polyurethane polymer materials at approximately 20 times magnification for six groups of densities. It can be seen that, on the microscopic scale, the material is composed of closely contacted and closed cells. The difference in the material density is mainly due to the structural characteristics of the cells, except for the density of the polymer matrix material. As the density increases, the shapes of the polymer cells tend to change from polygons to ellipses and circles, the cell diameter decreases, the cell spacing increases, and the porosity decreases.

For $0.11 \mathrm{~g} / \mathrm{cm}^{3}$ SEM image, in Figure 4(b) (magnified 100 times), the cell diameter is generally greater than $150 \mu \mathrm{m}$, the cell structure is irregular and nonuniform, and the cell crosssection is generally hexagonal. The contact surface (face) between each cell is large, and the faces with a thin film means that the cells have a high closed cell ratio. The strut is between two adjacent faces. The vertex is at strut intersection. Most of the matrix material is concentrated on the struts and vertices that make up the cell frame. In Figure 4(c) (magnified 200 times), the faces are generally greater than $50 \mu \mathrm{m}$, and the face shape is oval. There are usually twelve faces in the cell, which means that the cell is a dodecahedron. There are many triangle cut struts, and the struts are long and thin. It can be seen that struts play a major supporting role. Under load, struts will buckle and faces will crack [13].

For $0.25 \mathrm{~g} / \mathrm{cm}^{3}$ SEM image, in Figure 4(e) (magnified 100 times), the cell diameter is generally greater than $120 \mu \mathrm{m}$, and the cell structure is an ellipse with large ellipticity. The number of intracellular faces slightly decreased, and the face is relatively large. In Figure 4(f) (magnified 200 times), the faces are generally greater than $40 \mu \mathrm{m}$, and the face shape is round or oval. The number of intracellular faces decreased. The struts become thicker and shorter, and the triangle cut strut reduction. 


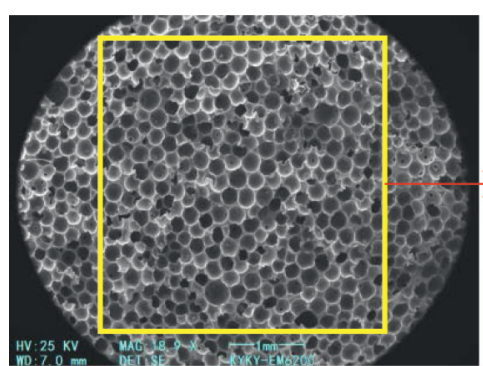

(a)

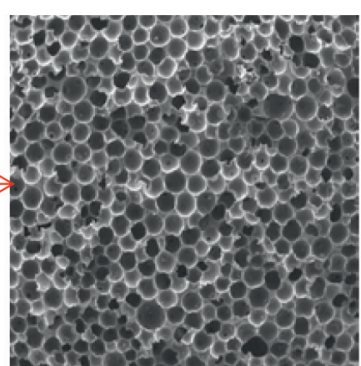

(b)

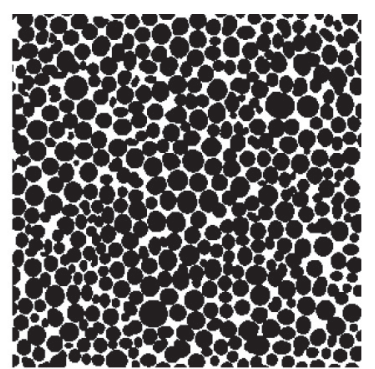

(c)

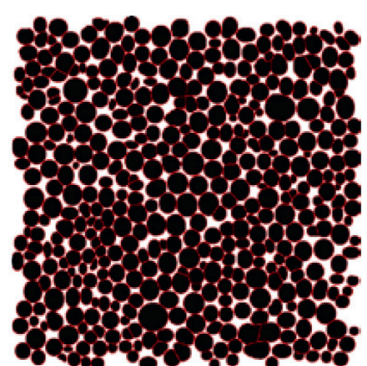

(d)

FIGURE 3: SEM image processing steps for the polyurethane polymer microstructure. (a) Raw SEM image; (b) cropped image; (c) reconstructed image; (d) removed and segmented image.

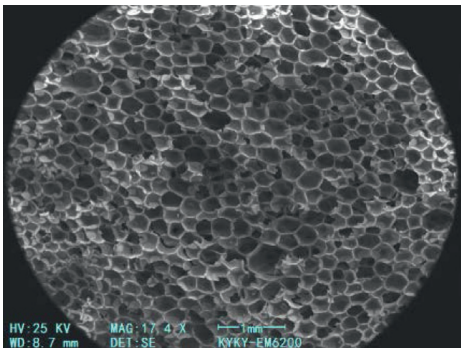

(a)

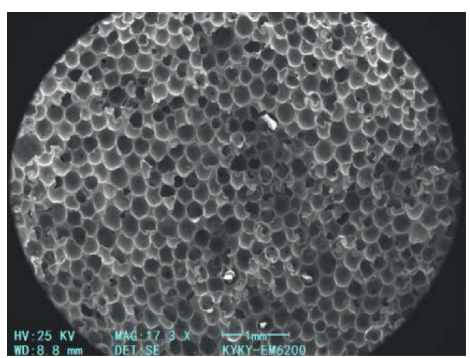

(d)

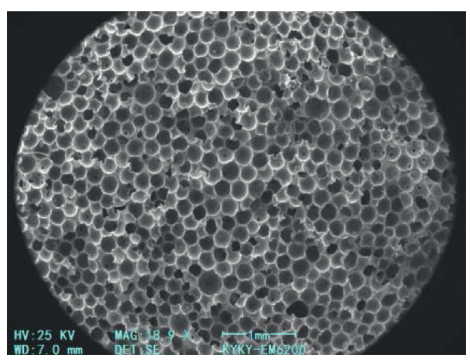

(g)

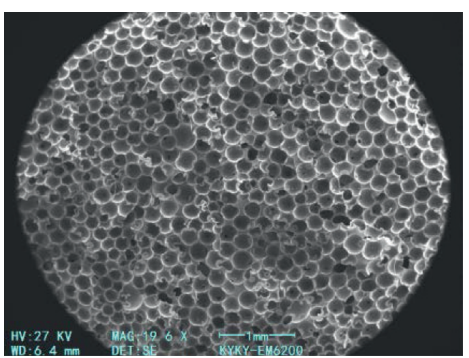

(j)

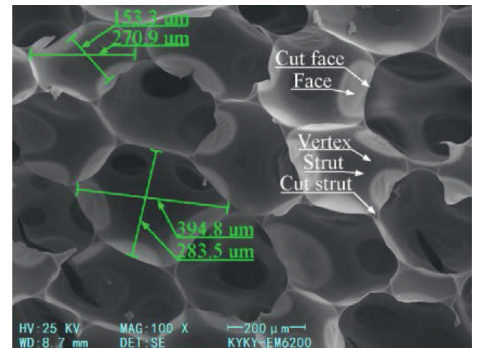

(b)

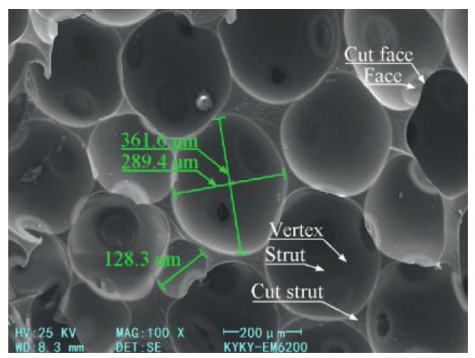

(e)

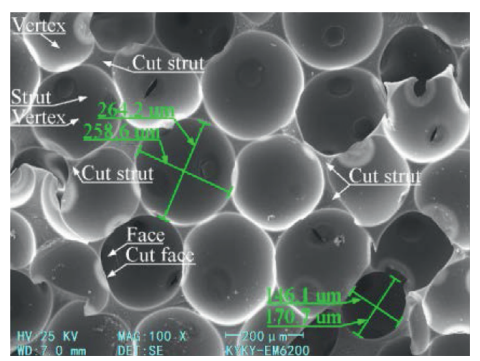

(h)

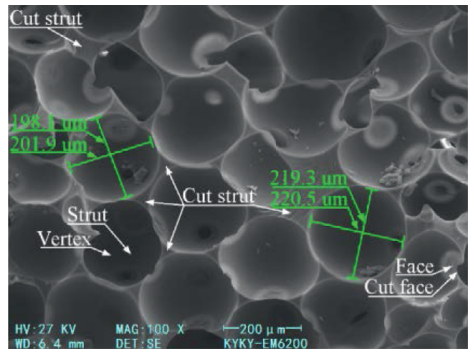

(k)

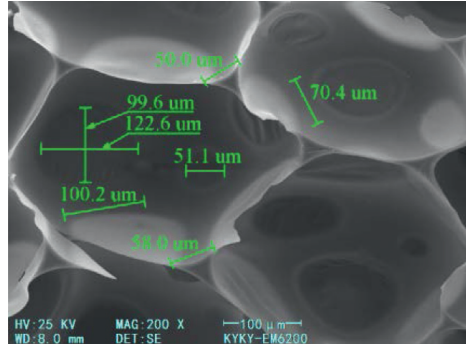

(c)

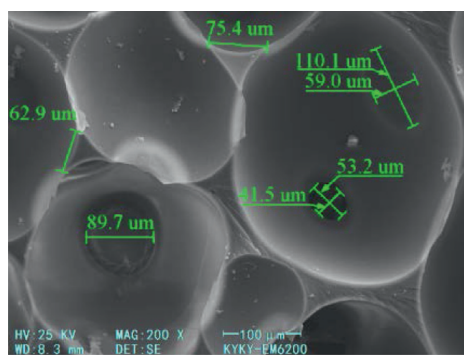

(f)

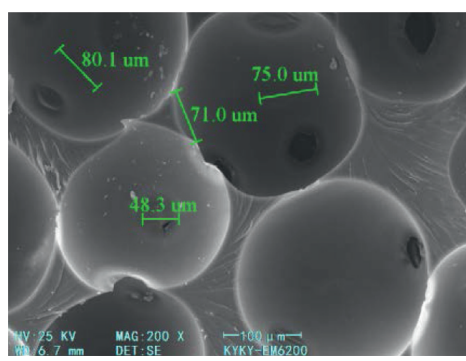

(i)

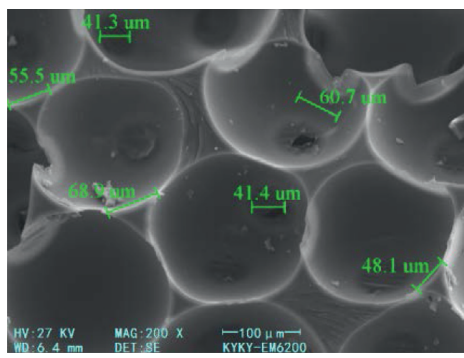

(1)

Figure 4: Continued. 


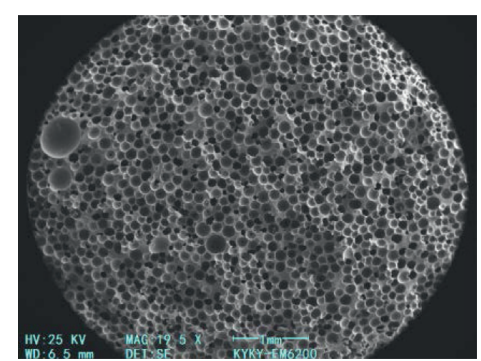

(m)

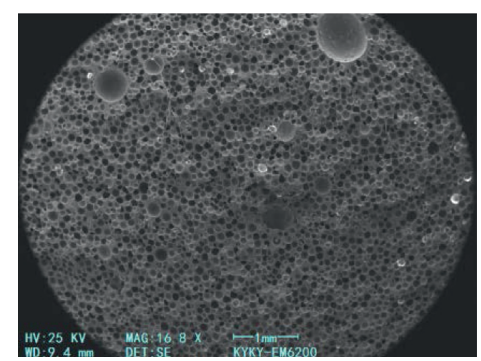

(p)

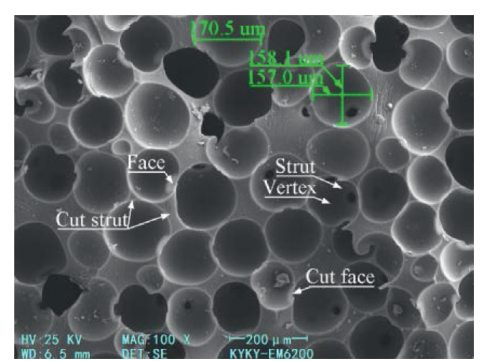

(n)

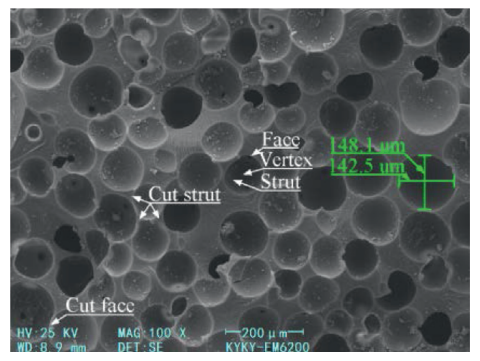

(q)

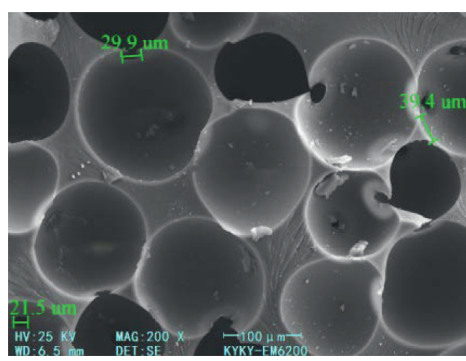

(o)

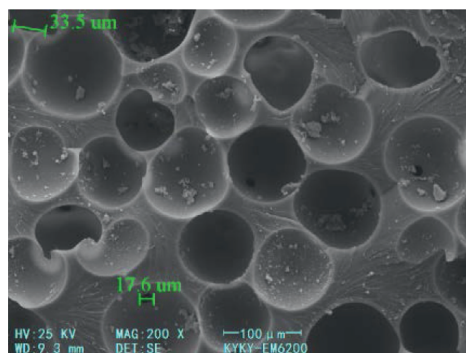

$(\mathrm{r})$

Figure 4: Microstructure of polymers at different densities. (a) $0.11 \mathrm{~g} / \mathrm{cm}^{3}$; (b) detail of (a); (c) detail of (b); (d) $0.25 \mathrm{~g} / \mathrm{cm}^{3}$; (e) detail of (d); (f) detail of (e); (g) $0.31 \mathrm{~g} / \mathrm{cm}^{3}$; (h) detail of (g); (i) detail of (h); (j) $0.40 \mathrm{~g} / \mathrm{cm}^{3}$; (k) detail of (j); (l) detail of (k); (m) $0.51 \mathrm{~g} / \mathrm{cm}^{3}$; (n) detail of (m); (o) detail of (n); (p) $0.56 \mathrm{~g} / \mathrm{cm}^{3}$; (q) detail of (p); (r) detail of (q).

For $0.31 \mathrm{~g} / \mathrm{cm}^{3}$ SEM image, in Figure 4(h) (magnified 100 times), the cell diameter is generally less than $260 \mu \mathrm{m}$, and the cell shape is circular or elliptical. The face is relatively small. The cells basically meet the closest packing. In Figure 4(i) (magnified 200 times), the faces are usually less than $50 \mu \mathrm{m}$, and the shape of the face tends to be circular. The number of triangle cut struts further reduces, the polygonal cut strut increases, and the length of strut is reduced.

For $0.40 \mathrm{~g} / \mathrm{cm}^{3}$ SEM image, in Figure 4(k) (magnified 100 times), the cell diameter is generally less than $220 \mu \mathrm{m}$, and the cell shape is an ellipse with very small ellipticity. Some adjacent cells do not contact each other and there are a lot of matrix materials between them, and the number of face further reduced. In Figure 4(1) (magnified 200 times), the faces are usually less than $40 \mu \mathrm{m}$, and the faces are with a thin film. The part of the adjacent triangular cut struts merges, and the struts are wide and short.

For $0.51 \mathrm{~g} / \mathrm{cm}^{3}$ SEM image, in Figure 4(n) (magnified 100 times), the cell diameter of the specimen is generally less than $180 \mu \mathrm{m}$, and the cell shape is round or oval with a small ellipticity. The face is extremely small. The matrix material of adjacent cells increased. In Figure 4(o) (magnified 200 times), the faces are usually less than $30 \mu \mathrm{m}$, and the number of intracellular faces decreased significantly. The cut strut of triangle is obviously reduced.

For $0.56 \mathrm{~g} / \mathrm{cm}^{3}$ SEM image, in Figure 4(q) (magnified 100 times), the cell diameter of the specimen is generally less than $150 \mu \mathrm{m}$, and the cell shape is basically round. There are almost no windows mean cells do not touch. There are a lot of matrix materials between cells. In Figure 4(r) (magnified 200 times), the faces are usually less than $20 \mu \mathrm{m}$. There are almost no triangle cut struts. It can be seen that the strength of polymer increases with the increase of matrix material content and cell spacing [16].
3.2. Statistical Analysis of the Polymer Cell Geometry. By observing the SEM morphology of the polyurethane polymer material, an intuitive understanding of the cell structure of the polymer is obtained, which provides a basis for determining the geometric characteristics of the cell. The statistical results of the roundness distribution, cell diameter distribution, and porosity are as follows.

\subsubsection{Section Roundness Distribution. Figure 5 is a section} cell roundness distribution diagram for polyurethane polymer samples of each density. It can be seen from Figure 4 that, for low-density materials, the section cells with a roundness between $90 \%$ and $100 \%$ account for only $50 \%$ to $70 \%$ of the total cells, and there are a few cells with a section roundness less than $75 \%$. The reason for this phenomenon is that the cells squeeze each other due to the increase in cell diameter, and the shape tends to be an ellipsoid or an irregular polyhedron. When the density of the polymer is higher than $0.3 \mathrm{~g} / \mathrm{cm}^{3}$, the proportion of cells with a section roundness of $90 \%$ to $100 \%$ is higher than $80 \%$, and the section roundness of most of the cells is higher than $75 \%$. Therefore, with the increase in density, the shape of the polymer cells tends to be round.

As shown in Table 2, the statistical parameters of the section roundness of the cells at each density is further calculated. It can be seen that as the density of the polymer increases, the average value of the section roundness of the cells increases. By comparing the average values and median of the section roundness at each density, it can be seen that the anisotropy of the cells in the specimen is not serious, especially that the high-density specimen is basically close to the ball, which may be related to the location of the sample in 


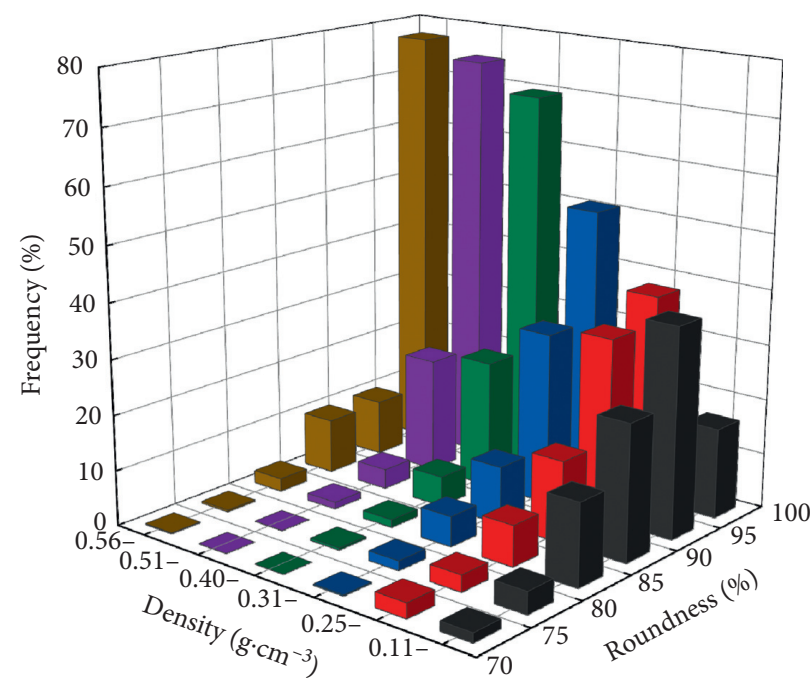

Figure 5: Section cell roundness distribution of polyurethane polymer samples of various densities.

TABLE 2: Summary of the statistical parameters of the section cell roundness.

\begin{tabular}{lccccc}
\hline Density $\left(\mathrm{g} / \mathrm{cm}^{3}\right)$ & Average $(\%)$ & Standard deviation & Minimum $(\%)$ & Median $(\%)$ & Maximum $(\%)$ \\
\hline 0.11 & 89.58 & 5.86 & 68.23 & 90.81 & 98.99 \\
0.25 & 91.43 & 6.70 & 60.68 & 93.75 & 99.81 \\
0.31 & 93.53 & 4.96 & 76.36 & 95.23 & 100 \\
0.40 & 95.66 & 3.48 & 81.73 & 96.71 & 96.25 \\
0.51 & 95.76 & 2.86 & 73.37 & 96.70 & 100 \\
0.56 & 95.90 & 3.93 & & & 960 \\
\hline
\end{tabular}

the specimen [10], so it is appropriate to use the average sphere size to characterize the cell size in (4). When the density exceeds $0.3 \mathrm{~g} / \mathrm{cm}^{3}$, the section roundness of the cells approaches $100 \%$, and this result indicates that the shape of the cells is closer to a sphere, and the macroscopic performance is close to isotropic.

3.2.2. Cell Diameter Distribution. Figure 6 is a section cell diameter distribution chart for the polyurethane polymer specimens with different densities. It can be seen from Figures 6(a)-6(f) that the section cell diameter distribution of each density specimen basically follows the normal distribution. As the density of the specimen increases, the length and endpoint of the section cell diameter distribution interval decreases. Figure 7 shows a summary of the section cell diameter distribution. It can be seen from Figure 7 that as the density of the specimen increases, the overall size of the section cell diameter decreases, and the degree of dispersion of the section cell diameter distribution also decreases. And the average section cell diameter and standard deviation of the specimens at each density are negatively correlated with the density.

As shown in Table 3, the statistical parameters of the section cell diameter distribution of the cells at each density is further calculated. With the increase of density, the statistical parameters tend to decrease.
According to (5), the average section cell area measured by the computer two-dimensional image analysis software Image-Pro Plus is transformed into the cell diameter. According to (6), the standard deviation of the cell crosssection area is converted into the standard deviation of the cell diameter. In this way, the measured two-dimensional area can be transformed from SEM image to three-dimensional cell diameter and distribution. The average cell diameter, standard deviation, and density of the polymer materials were fitted, and it is found that they have a basically linear relationship. Figure 8 is a fitting graph of each cell diameter parameter and density.

As shown in Figure 8(a), a linear fitting of the average cell diameter and density can be obtained as follows:

$$
D=-371.19 \rho+323.29 \text {, }
$$

where $D$ is the average cell diameter, and $\rho$ is the polymer density.

As shown in Figure 8(b), a linear fitting of the standard deviation and density of the cell diameter distribution can be obtained as follows:

$$
S_{D}=-172.22 \rho+143.93
$$

where $S_{D}$ is the standard deviation of the cell diameter distribution, and $\rho$ is the polymer density.

The quantification of cell size is helpful to understand the influence of microstructure on the mechanical properties of 


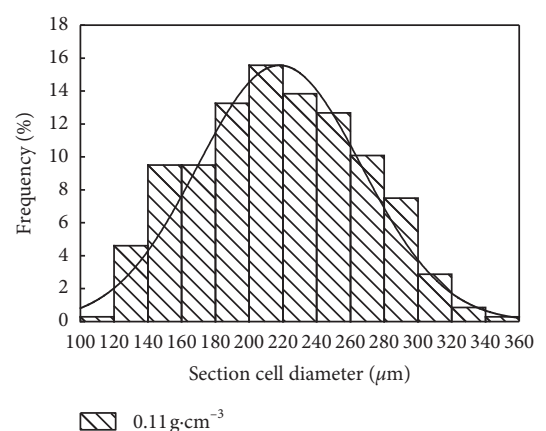

(a)

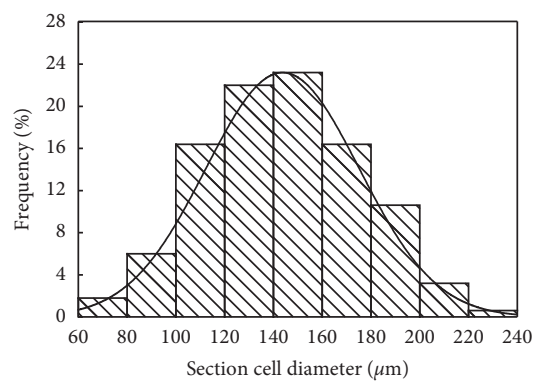

$\Delta \nabla .40 \mathrm{~g} \cdot \mathrm{cm}^{-3}$

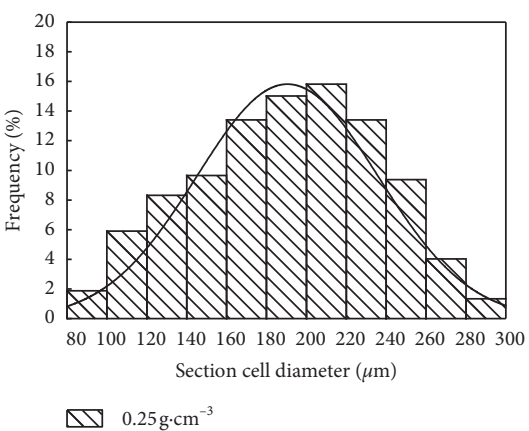

(b)

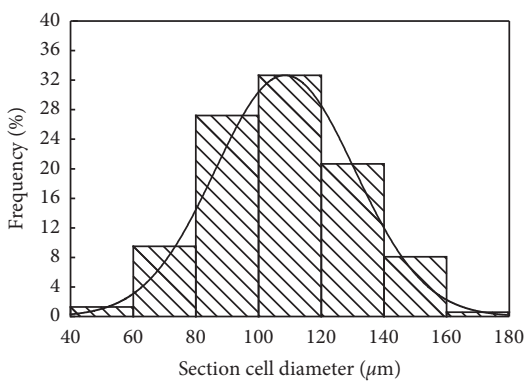

$\Delta \nabla 0.51 \mathrm{~g} \cdot \mathrm{cm}^{-3}$

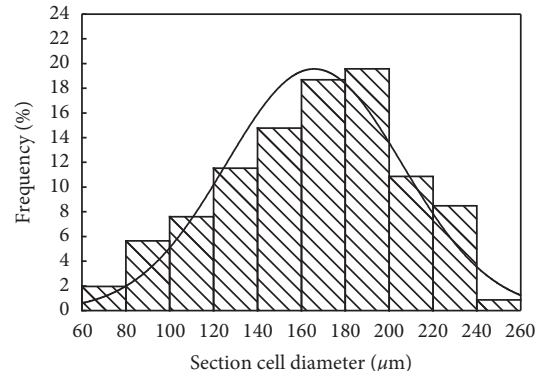

$\nabla 0.31 \mathrm{~g} \cdot \mathrm{cm}^{-3}$

(c)

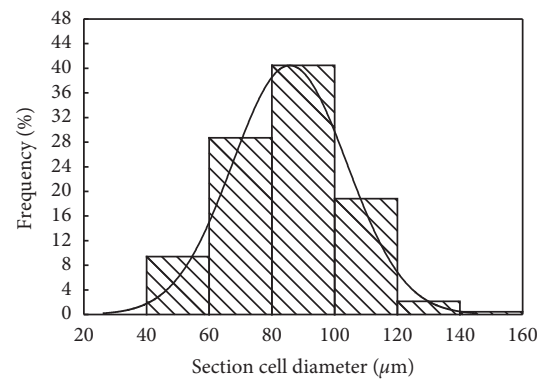

$\nabla 0.56 \mathrm{~g} \cdot \mathrm{cm}^{-3}$

(d)

(e)

(f)

FIGURE 6: Section cell diameter distribution of polyurethane polymer samples. (a) $0.11 \mathrm{~g} / \mathrm{cm}^{3}$; (b) $0.25 \mathrm{~g} / \mathrm{cm}^{3} ;$ (c) $0.31 \mathrm{~g} / \mathrm{cm}^{3}$; (d) $0.40 \mathrm{~g} / \mathrm{cm}^{3}$; (e) $0.51 \mathrm{~g} / \mathrm{cm}^{3}$; (f) $0.56 \mathrm{~g} / \mathrm{cm}^{3}$.

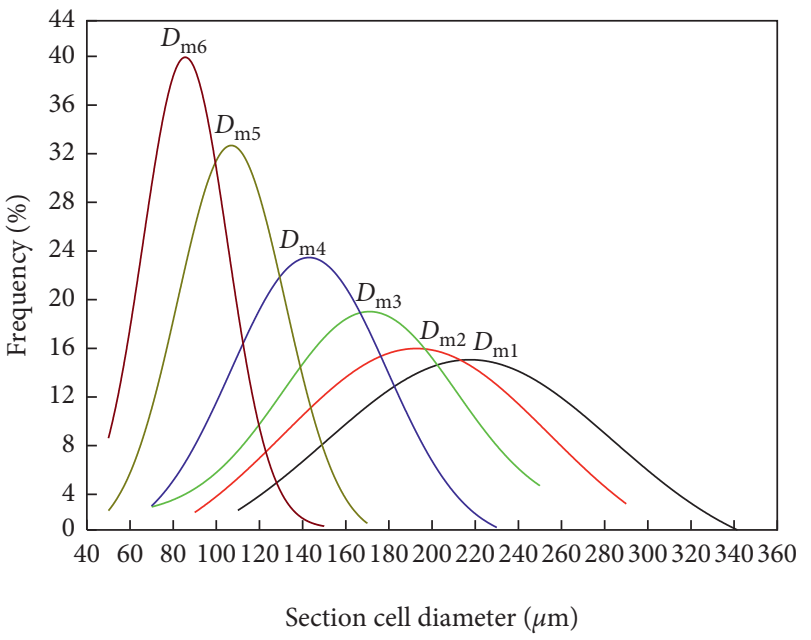

$\begin{array}{lll}\text { Normal curve fitting } & D_{\mathrm{m} 1}=218.00 \mu \mathrm{m}_{1} & \mathrm{~S}_{1}=48.60 \\ -0.11 \mathrm{~g} \cdot \mathrm{cm}^{-3} & D_{\mathrm{m} 2}=190.50 \mu \mathrm{m}_{2} & \mathrm{~S}_{2}=45.49 \\ -0.25 \mathrm{~g} \cdot \mathrm{cm}^{-3} & D_{\mathrm{m} 3}=165.80 \mu \mathrm{m} & \mathrm{S}_{3}=40.11 \\ -0.31 \mathrm{~g} \cdot \mathrm{cm}^{-3} & D_{\mathrm{m} 4}=143.74 \mu \mathrm{m} & \mathrm{S}_{4}=31.48 \\ -0.40 \mathrm{~g} \cdot \mathrm{cm}^{-3} & D_{\mathrm{m} 5}=108.44 \mu \mathrm{m}_{5} & \mathrm{~S}_{5}=22.30 \\ -0.51 \mathrm{~g} \cdot \mathrm{cm}^{-3} & D_{\mathrm{m} 6}=85.68 \mu \mathrm{m} & \mathrm{S}_{6}=18.25\end{array}$

Figure 7: Summary of the section cell diameter distribution $\left(D_{\mathrm{m} 1}-D_{\mathrm{m} 6}\right.$ are the average section cell diameters, and $S_{1}-S_{6}$ are the standard deviations).

materials. When the cell size is large, the compressive property of the material is mainly determined by the strut. According to the previous studies, the critical cell size of the turning point which defines the influence of cell size on compressive strength increases with the increase of density. The results show that the cell size of $0.60 \mathrm{~g} / \mathrm{cm}^{3}$ 
TABLE 3: Summary of the statistical parameters of the section cell diameter distribution.

\begin{tabular}{lccccc}
\hline Density $\left(\mathrm{g} / \mathrm{cm}^{3}\right)$ & Average $(\mu \mathrm{m})$ & Standard deviation & Minimum $(\mu \mathrm{m})$ & Median $(\mu \mathrm{m})$ & Maximum $(\mu \mathrm{m})$ \\
\hline 0.11 & 218.00 & 48.60 & 111.05 & 215.39 & 350.56 \\
0.25 & 190.50 & 45.49 & 92.44 & 70.98 & 286.29 \\
0.31 & 165.80 & 40.11 & 64.26 & 170.85 & 253.20 \\
0.40 & 143.74 & 31.48 & 50.76 & 144.11 & 230.41 \\
0.51 & 108.44 & 22.30 & 42.54 & 85.92 & 178.38 \\
0.56 & 85.68 & 18.25 & & & 147.25 \\
\hline
\end{tabular}

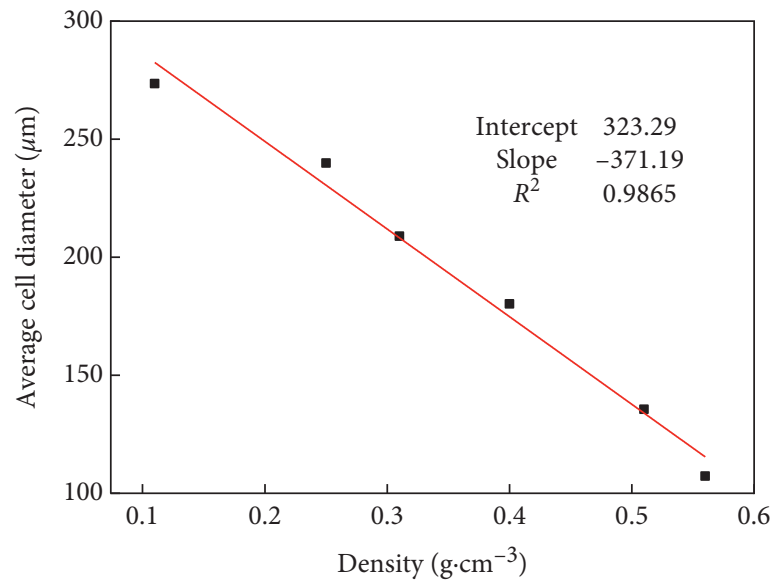

- Test point

- Linear fit

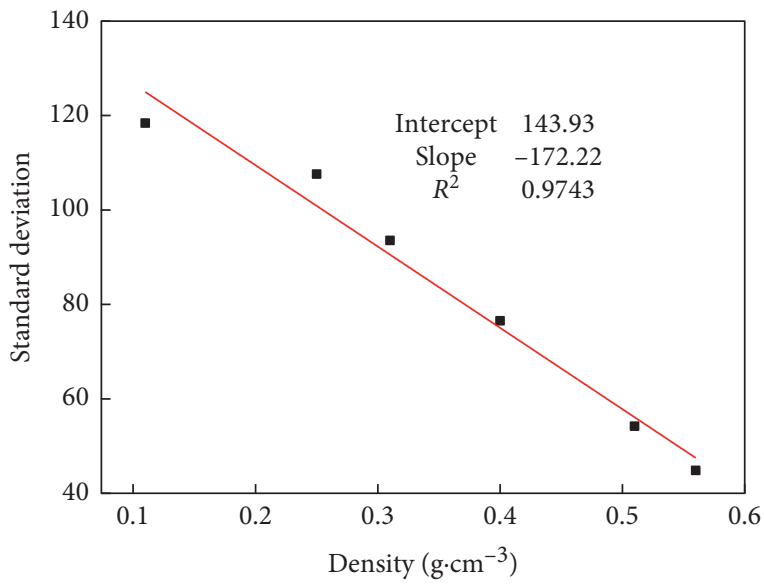

- Test point

- Linear fit

(a)

(b)

FIGURE 8: Relationship between cell diameter and density. (a) Relationship between average cell diameter and density; (b) relationship between standard deviation and density.

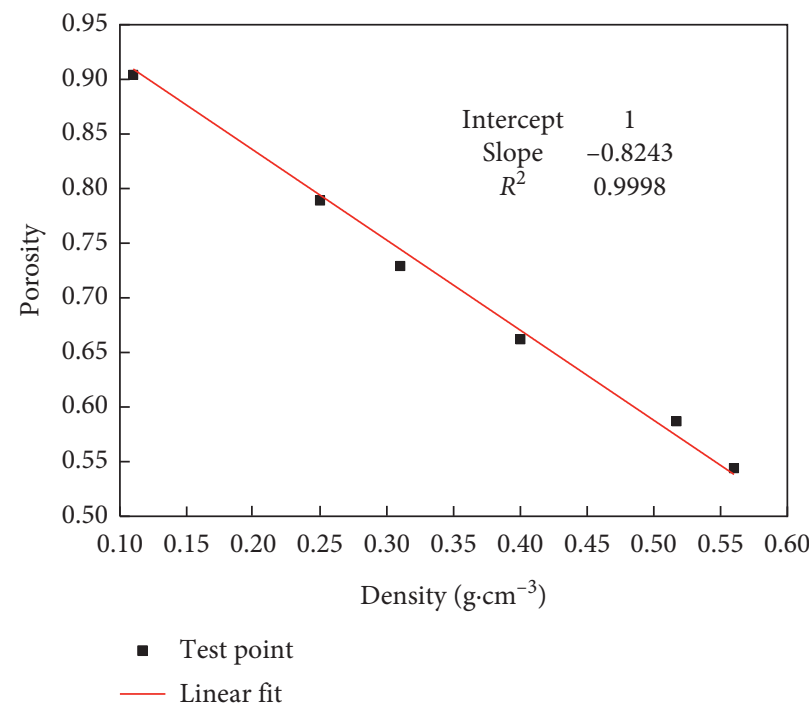

FIGURE 9: Relationship between porosity and density.

specimen is more than $60 \mu \mathrm{m}$, which is larger than the critical cell size [41]. Therefore, it can be inferred that the compression failure of materials is caused by the yielding of struts [11].
3.2.3. Polymer Porosity. The density of the polyurethane polymer material is obviously related to the polymer porosity and density of the matrix. As shown in Figure 9, as the density increases, the polymer porosity decreases. 
A linear fit of the porosity and density of the polymer yields the following relationship:

$$
f=-0.8243 \rho+1 .
$$

In this formula, $f$ is the porosity, and $\rho$ is the polymer density.

According to (11), when the porosity is 0 , the polymer matrix density is $1.21 \mathrm{~g} / \mathrm{cm}^{3}$. It is basically consistent with the description in literature [42] that the matrix density of rigid polyurethane foam is about $1.2 \mathrm{~g} / \mathrm{cm}^{3}$.

\section{Conclusions}

In this study, micromorphology SEM images of the specimens were observed, and feature parameters were counted. The microstructural information obtained in this study will help establish a cell-based model to explain the mechanical response of rigid polymer foams. The main results and conclusions are as follows:

(1) The cells of the low-density polymer material are deformed due to the mutual extrusion of the cells, which are irregular polyhedrons or ellipsoids. Therefore, low-density polymer materials have anisotropy. As the density increases and exceeds $0.3 \mathrm{~g} / \mathrm{cm}^{3}$, the cell structure tends to be spherical, and the polymer materials are close to isotropic.

(2) The section cell diameters in the same specimen obey a normal distribution, and the section average cell diameter, standard deviation, the length and endpoint of the section cell diameter distribution interval decrease as the density of the specimen increases. The cell diameter and standard deviation have linear negative correlations with the density.

(3) The porosity of the polymer has a linear negative correlation with the density. The polymer matrix has a density of $1.21 \mathrm{~g} / \mathrm{cm}^{3}$.

\section{Data Availability}

The data used in the paper are available from the authors upon request.

\section{Conflicts of Interest}

The authors declare that there are no conflicts of interest regarding the publication of this paper.

\section{Acknowledgments}

The authors would like to acknowledge the financial support received from the National Key Research and Development Program of China (no. 2018YFC1508401) and the Open Fund Project of State Key Laboratory of Road Engineering Safety and Health in Cold and High-Altitude Regions of China (no. YGY2017KYPT-03).

\section{References}

[1] H. Liu, F. Wang, M. Shi, and W. Tian, "Mechanical behavior of polyurethane polymer materials under triaxial cyclic loading: a particle flow code approach," Journal of Wuhan University of Technology, vol. 33, no. 4, pp. 980-986, 2018.

[2] M. Hao, F. Wang, X. Li, B. Zhang, and Y. Zhong, "Numerical and experimental studies of diffusion law of grouting with expansible polymer," Journal of Materials in Civil Engineering, vol. 30, no. 2, 2018.

[3] M. Shi, F. Wang, and J. Luo, "Compressive strength of polymer grouting material at different temperatures," Journal of Wuhan University of Technology, vol. 25, no. 6, pp. 962-965, 2010.

[4] M. Shi, Research on polymer grouting material properties and directional fracturing grouting mechanism for dykes and dams, $\mathrm{PhD}$ Thesis, Dalian University of Technology, Dalian, China, 2010.

[5] N. Rana and R. Nair, "Performance of polyurethane grouting to handle heavy seepage in tunnels," in Proceedings of the Conference on Recent Advances in Rock Engineering (RARE), Bengaluru, India, 2016.

[6] O. Buzzi, S. Fityus, Y. Sasaki, and S. Sloan, "Structure and properties of expanding polyurethane foam in the context of foundation remediation in expansive soil," Mechanics of Materials, vol. 40, no. 12, pp. 1012-1021, 2008.

[7] H. Fang, B. Li, F. Wang, Y. Wang, and C. Cui, "The mechanical behaviour of drainage pipeline under traffic load before and after polymer grouting trenchless repairing," Tunnelling and Underground Space Technology, vol. 74, pp. 185-194, 2018.

[8] H. Fang, Y. Su, X. Du, F. Wang, and B. Li, "Experimental and numerical investigation on repairing effect of polymer grouting for settlement of high-speed railway unballasted track," Applied Sciences, vol. 9, p. 21, 2019.

[9] C. Guo, B. Sun, D. Hu, F. Wang, M. Shi, and X. Li, "A field experimental study on the diffusion behavior of expanding polymer grouting material in soil," Soil Mechanics and Foundation Engineering, vol. 56, no. 3, pp. 171-177, 2019.

[10] M. C. Hawkins, B. O’Toole, and D. Jackovich, "Cell morphology and mechanical properties of rigid polyurethane foam," Journal of Cellular Plastics, vol. 41, no. 3, pp. 267-285, 2005.

[11] Y. Wei, F. Wang, X. Gao, and Y. Zhong, "Microstructure and fatigue performance of polyurethane grout materials under compression," Journal of Materials in Civil Engineering, vol. 29, no. 9, 2017.

[12] L. Shi and Z.-M. Li, "Morphology development of highdensity rigid polyurethane foam upon compression by on-line scanning electronic microscope," Journal of Applied Polymer Science, vol. 105, no. 4, pp. 2008-2011, 2007.

[13] K. Liu, W. Liang, F. Ren, J. Ren, F. Wang, and H. Ding, "The study on compressive mechanical properties of rigid polyurethane grout materials with different densities," Construction and Building Materials, vol. 206, pp. 270-278, 2019.

[14] E. Linul, D. A. Şerban, L. Marsavina, and T. Sadowski, "Assessment of collapse diagrams of rigid polyurethane foams under dynamic loading conditions," Archives of Civil and Mechanical Engineering, vol. 17, no. 3, pp. 457-466, 2017.

[15] M. Ridha and V. P. W. Shim, "Microstructure and tensile mechanical properties of anisotropic rigid polyurethane foam," Experimental Mechanics, vol. 48, no. 6, pp. 763-776, 2008. 
[16] X. Zheng, "Study on relationship between density and mechanical behavior of high polymer grouting materials," Journal of Wuhan University of Technology, vol. 36, no. 4, pp. 44-47, 2014.

[17] J. Wu, Y. He, and Z. Yu, "Failure mechanism of rigid polyurethane foam under high temperature vibration condition by experimental and finite element method," Journal of Applied Polymer Science, vol. 137, no. 6, 2019.

[18] Y. He, J. Wu, D. Qiu, and Z. Yu, "Experimental and numerical analyses of thermal failure of rigid polyurethane foam," Materials Chemistry and Physics, vol. 233, pp. 378-389, 2019.

[19] K. Mader, R. Mokso, C. Raufaste et al., "Quantitative 3D characterization of cellular materials: segmentation and morphology of foam," Colloids and Surfaces A: Physicochemical and Engineering Aspects, vol. 415, pp. 230-238, 2012.

[20] S. Pérez-Tamarit, E. Solórzano, A. Hilger, I. Manke, and M. A. Rodríguez-Pérez, "Multi-scale tomographic analysis of polymeric foams: a detailed study of the cellular structure," European Polymer Journal, vol. 109, pp. 169-178, 2018.

[21] Z. Zakaria, Z. Mohamad Ariff, and A. Abu Bakar, "Monitoring deformation mechanism of foam cells in polyethylene foams via optical microscopy: effect of density and microstructure," Journal of Cellular Plastics, vol. 54, no. 6, pp. 957-976, 2018.

[22] C. Yang, Z.-H. Zhuang, and Z.-G. Yang, "Pulverized polyurethane foam particles reinforced rigid polyurethane foam and phenolic foam," Journal of Applied Polymer Science, vol. 131, no. 1, 2014.

[23] E. Esmaeilnezhad, M. Rezaei, and M. K. Razavi, “The effect of alternative blowing agents on microstructure and mechanical characteristics of rigid polyurethane foam," Iranian Polymer Journal, vol. 18, no. 7, pp. 569-579, 2009.

[24] J. R. Dawson and J. B. Shortall, "The microstructure of rigid polyurethane foams," Journal of Materials Science, vol. 17, no. 1, pp. 220-224, 1982.

[25] J. Reignier, P. Alcouffe, F. Mechin, and F. Fenouillot, "The morphology of rigid polyurethane foam matrix and its evolution with time during foaming - new insight by cryogenic scanning electron microscopy," Journal of Colloid and Interface Science, vol. 552, pp. 153-165, 2019.

[26] J. Pinto, E. Solórzano, M. A. Rodriguez-Perez, and J. A. de Saja, "Characterization of the cellular structure based on user-interactive image analysis procedures," Journal of Cellular Plastics, vol. 49, no. 6, pp. 555-575, 2013.

[27] K. M. Lewis, I. Kijak, K. B. Reuter, and J. B. Szabat, "An image analysis method for cell-size and cell-size distribution measurement in rigid foams," Journal of Cellular Plastics, vol. 32, no. 3, pp. 235-259, 1996.

[28] D. L. Sahagian and A. A. Proussevitch, "3D particle size distributions from 2D observations: stereology for natural applications," Journal of Volcanology and Geothermal Research, vol. 84, no. 3, pp. 173-196, 1998.

[29] R. Garcia-Gonzales, C. Monnereau, J. F. Thovert, P. M. Adler, and M. Vigners-Adler, "Conductivity of real foams," Colloids and Surfaces A: Physicochemical and Engineering Aspects, vol. 151, no. 3, pp. 497-503, 1999.

[30] F. De Pascalis, M. Nacucchi, M. Scatto, and R. Albertoni, "Quantitative characterisation of low-density, high performance polymeric foams using high resolution X-ray computed tomography and laser confocal microscopy," NDT \& E International, vol. 83, pp. 123-133, 2016.

[31] G. Ovarlez, K. Krishan, and S. Cohen-Addad, "Investigation of shear banding in three-dimensional foams," Europhysics Letters, vol. 91, no. 6, Article ID 68005, 2010.
[32] J. Braun, M. O. Klein, J. Bernarding, M. B. Leitner, and H. D. Mika, "Non-destructive, three-dimensional monitoring of water absorption in polyurethane foams using magnetic resonance imaging," Polymer Testing, vol. 22, no. 7, pp. 761-767, 2003.

[33] M. Marvi-Mashhadi, C. S. Lopes, and J. Llorca, "Modelling of the mechanical behavior of polyurethane foams by means of micromechanical characterization and computational homogenization," International Journal of Solids and Structures, vol. 146, pp. 154-166, 2018.

[34] M. D. Montminy, Complete structural characterization of foam using $3 \mathrm{D}$ images, $\mathrm{PhD}$ Thesis, University of Minnesota, Ann Arbor, MI, USA, 2001.

[35] M. D. Montminy, A. R. Tannenbaum, and C. W. Macosko, "The 3D structure of real polymer foams," Journal of Colloid and Interface Science, vol. 280, no. 1, pp. 202-211, 2004.

[36] General Administration of Quality Supervision, "Inspection and quarantine of the People's Republic of China, standardization administration of the People's Republic of China," Rigid Cellular Plastics-Determination of Compression Properties, Standards Press of China, China, 2008.

[37] General Administration of Quality Supervision, "Inspection and quarantine of the People's Republic of China and standardization administration of the People's Republic of China," Cellular Plastics and Rubbers-Determination of Apparent Density, Standards Press of China, China, 2009.

[38] General Administration of Quality Supervision, "Inspection and quarantine of the People's Republic of China," Test Method for Average Cell Size of Rigid Cellular Plastics, Standards Press of China, China, 1991.

[39] J. Xu, T. Wu, J. W. Zhang, H. Chen, W. Sun, and C. Peng, "Microstructure measurement and microgeometric Packing characterization of rigid polyurethane foam defects," Cellular Polymers, vol. 36, no. 4, pp. 183-204, 2017.

[40] M. B. Rhodes and B. Khaykin, "Foam characterization and quantitative stereology," Langmuir, vol. 2, no. 5, pp. 643-649, 1986.

[41] G. F. Smits, "Effect of cellsize reduction on polyurethane foam physical properties," Journal of Thermal Insulation and Building Envelopes, vol. 17, no. 4, pp. 309-329, 1994.

[42] L. J. Gibson and M. F. Ashby, "The mechanics of three-dimensional cellular materials," Proceedings of the Royal Society of London. A. Mathematical and Physical Sciences, vol. 382, no. 1782, pp. 43-59, 1982. 